\title{
Analisis Kepuasan Mahasiswa Terhadap Kualitas Layanan Program Studi Bisnis Jasa Makanan FEB-UAD
}

\author{
Wardiyanta $^{\mathrm{a}, 1, *}$, Retnosyari Septiyani ${ }^{\mathrm{b}, 2}$ \\ ${ }^{a}$ Magister Manajemen UAD, J1. Pramuka No 42 Yogyakarta, 55161, Indonesia \\ b Bisnis Jasa Makanan UAD, Jl. Pramuka No 42 Yogyakarta, 55161, Indonesia \\ ${ }^{1}$ wardiyanta@culinary.uad.ac.id; ${ }^{2}$ retnosyari.septiyani@culinary.uad.ac.id \\ * penulis korespondensi
}

\begin{abstract}
This study aims to assist the management of the Food Services study program in evaluating services, directing improvement efforts by increasing weak service attributes so that the services provided by the study program can provide satisfaction to those who use their services. This research, which integrates the Servqual and QFD methods, was conducted in the UAD Food Service Business Study Program using a mixed quantitative and qualitative research design. The research is based on a survey of students who are users of the services of this study program. The results of this study are expected to be one of the references in the formulation of the UAD Food Service Business study program development plan. Besides that, it can also function as a supporter of higher education management development, especially regarding the concept of Total Quality Management in Education.
\end{abstract}

Keywords: education, resource management, total quality management

\section{ABSTRAK}

Penelitian ini bertujuan untuk membantu pihak manajemen Program Studi Bisnis Jasa Makanan dalam melakukan evaluasi terhadap layanan, mengarahkan upaya-upaya perbaikan dengan meningkatkan atribut pelayanan yang lemah sehingga jasa yang diberikan oleh program studi dapat memberikan kepuasan pada para pihak yang menggunakan jasanya. Penelitian yang mengintegrasikan metode Servqual dan QFD ini dilakukan di Program Studi Bisnis Jasa Makanan UAD dengan menggunakan desain penelitian campuran antara kuantitatif dan kualitatif. Penelitian didasarkan pada survei terhadap mahasiswa yang menjadi pengguna jasa program studi ini. Hasil penelitian ini diharapkan dapat menjadi salah satu rujukan dalam perumusan rencana pengembangan program studi Bisnis Jasa Makanan UAD. Selain itu juga dapat berfungsi sebagai pendukung pengembangan manajemen perguruan tinggi, khususnya tentang konsep Total Quality Management in Education.

Kata Kunci: manajemen sumber daya, pendidikan, total quality manajemen

\section{Pendahuluan}

Sistem Manajemen Mutu ISO secara umum menggunakan delapan klausul/prinsip utama, yaitu: berfokus pada pelanggan, kepemimpinan, peran serta setiap orang di dalam organisasi, pendekatan proses, pendekatan sistem, peningkatan terus menerus, pengambilan keputusan dengan pendekatan fakta, serta hubungan baik dengan pemasok (Prabowo, 2009). Salah satu prinsip ISO menyebutkan bahwa pengukuran kepuasan pelanggan wajib dilakukan sebagai umpan balik dari pelanggan terhadap sistem yang diterapkan (Tjiptono, 2011). Keberhasilan sebuah lembaga sangat ditentukan oleh mutu 
layanan yang diberikan. Pelayanan yang bermutu dapat diidentifikasikan melalui kepuasan pelanggan. Sebagai lembaga pendidikan maka proses akademik merupakan proses inti, oleh karena itu pengukuran kepuasan pelanggan pada proses ini wajib dilakukan secara periodik.

Kasetwar (2008) menyebutkan kategori pemangku kepentingan utama dari institusi pendidikan tinggi adalah: pelajar, pendidik, orang tua, fakultas, manajemen institusi, industri, badan hukum, pelatih, penyedia pinjaman pendidikan, peneliti dan akademisi, masyarakat, politisi, peradilan. Marić (2013), menyebutkan kategori pemangku kepentingan dan kelompok konstitusi untuk lembaga pendidikan tinggi adalah: entitas pemerintah, administrasi, karyawan, pelanggan, pemasok, pesaing, donor, masyarakat, regulator pemerintah, regulator non-pemerintah, perantara keuangan, dll. Pengakuan mahasiswa sebagai pemangku kepentingan diperkenalkan dalam literatur pada pertengahan 1970-an (Douglas dkk, 1993) dan pentingnya mahasiswa sebagai kategori pemangku kepentingan telah tumbuh dan universitas diharapkan untuk memberikan akuntabilitas, kualitas, efektivitas dan efisiensi (Jongbloed dkk. 2008). Lembaga pendidikan tinggi perlu mengidentifikasi kebutuhan dan permintaan mereka karenamahasiswa sebagai pemangku kepentingan dilihat sebagai pelanggan dan kepuasan pelanggan terkait dengan kualitas layanan. Mengikuti pendapat Leisyte et al. (2011), mahasiswa sebagai pemangku kepentingan perlu dilibatkan dalam manajemen mutu dan proses penjaminan kualitas internal pada tingkat yang lebih tinggi lembaga pendidikan sebagai mitra setara.

Kepuasan konsumen adalah penilaian bahwa fitur produk atau jasa atau produk/jasa, memberikan tingkat pemenuhan berkaitan dengan konsumsi yang menyenangkan, termasuk tingkat under fulfillment dan over-fulfillment (Tjiptono dkk, 2011). Seorang pelanggan, jika merasa puas dengan nilai yang diberikan oleh produk atau jasa, besar kemungkinan menjadi konsumen atau pelanggan dalam waktu yang lama. Menurut Kotler dan Keller (2012) "satisfaction is a person's feelings of pleasure or disappointment that result from comparing a product's perceived performance (or outcome) to expectations.". Lovelock dan Wirtz (2011) berpendapat bahwa kepuasan adalah suatu sikap yang diputuskan berdasarkan pengalaman yang didapatkan. Sangat dibutuhkan penelitian untuk membuktikan ada atau tidaknya harapan sebelumnya yang merupakan bagian terpenting dalam kepuasan.

Dengan kompleksnya kualitas layanan itu maka tidak mudah menemukan definisi tunggal yang mencakup keseluruhannya. Salah satu batasan dikemukakan oleh Stamatis (1996), yang menyebutkan bahwa TQM adalah suatu system manajemen strategik yang integratif, melibatkan semua manajer dan karyawan, serta menggunakan metode-metode kualitatif dan kuantitatif untuk memperbaiki proses organisasi secara berkesinambungan agar dapat memenuhi dan melebihi kebutuhan, keinginan dan harapan pelanggan. Menurut Parasuraman dan Zeithaml (1985), kualitas adalah konstruksi yang sulit dipahami dan tidak jelas. Definisi apa pun yang digunakan, semuanya datang ke konsumen layanan (misalnya pengalamannya, harapannya) dan tujuan jangka panjang dari penyedia layanan adalah untuk memuaskan konsumen, memperkuat hubungan dengan penyedia layanan dan mencapai loyalitas konsumen. Mereka mengusulkan model yang didasarkan pada skala multiple sitem untuk mengukur kualitas layanan, yakni model SERVQUAL (Tjiptono dkk, 2016). Model ini juga sering disebut Gap Analysis Model terkait dengan kesenjangan yang terjadi antara harapan dan persepsi pelanggan atau 
berkaitan dengan kepuasan pelanggan. Kualitas pelayanan mencerminkan perbandingan antara tingkat layanan yang diberikan perusahan atau organisasi dibandingkan dengan harapan pelanggan (Tjiptono, 2011).

Hill (1995) membahas aspek kualitas layanan dalam pendidikan tinggi dan melakukan penelitian di Inggris yang berfokus pada peran siswa sebagai konsumen utama yang mengukur harapan dan persepsi mereka. Pendidikan tinggi di negara berkembang memiliki masalah kualitas yang serius dan De Oliviera dan Fereira (2009) menggunakan SERVQUAL untuk mengidentifikasi kesenjangan antara harapan dan persepsi siswa dan untuk menyesuaikan skala generik SERVQUAL untuk sektor pendidikan tinggi di Brasil.

Zafiropoulos dan Vrana (2008) menilai kualitas layanan dalam pendidikan tinggi Yunani menggunakan model ini berdasarkan kuesioner yang disesuaikan dalam konteks pendidikan dan termasuk siswa dan staf dalam penelitian. Penelitian menunjukkan bahwa hasil staf berbeda secara signifikan dari nilai siswa yang menunjukkan kesenjangan dalam cara siswa dan staf akademik mempersepsikan kualitas pendidikan. Dado et al. (2011) melakukan penyelidikan empiris terhadap konstruk kualitas layanan pendidikan tinggi menggunakan skala SERVQUAL di Serbia dan menyimpulkan ada kesenjangan yang signifikan antara harapan dan persepsi siswa. Menurut Beaumont (2012), mahasiswa adalah pemangku kepentingan utama untuk lembaga pendidikan tinggi dan oleh karena itu menilai kualitas layanan dari sudut pandang mereka sangat penting untuk membuat perbaikan di lembaga pendidikan tinggi.

Berlandaskan pemahamam mutu diatas, dapat dikatakan bahwa saat ini pendidikan bukan lagi sebatas kemampuan untuk semata menghasilkan lulusan yang diukur secara akademik, tetapi sudah mengarah pada suatu bentuk kualitas pendidikan secara menyeluruh (Total Quality Education) yang berorientasi pada kepuasan pelanggan. Kualitas layanan dalam pendidikan tinggi penting untuk keberhasilan suatu lembaga (Landrum, 2007). Galloway (1998) menyatakan bahwa kualitas layanan sangat penting bagi institusi pendidikan tinggi karena sejumlah alasan, diantaranya untuk mencapai keunggulan kompetitif, memenuhi persyaratan pemerintah, dan memenuhi harapan publik. Dalam rangka untuk mewujudkan pendidikan berkulitas itu, program studi ini akan menerapkan manajemen mutu terpadu, atau yang dikenal dengan Total Quality Education (TQE).

Manajemen mutu pendidikan Total Quality Education (TQE) menekankan pada perbaikan manajemen secara konsisten dan berkelanjutan untuk memenuhi kebutuhan dan mencapai kepuasan pelanggan. Program studi perlu melakukan evaluasi atas kualitas pelayanan yang diberikan kepada pemakai jasa layanan, dalam hal ini kepada mahasiswa, karyawan non edukatif, dan karyawan edukatif serta pengguna jasa lainnya. Evaluasi kualitas pelayanan dapat dilakukan dengan cara mencari kesenjangan antara pelayanan yang sesungguhnya diharapkan oleh mahasiswa, karyawan non edukatif, dan karyawan edukatif, dengan persepsi mengenai kualitas pelayanan yang diterima mereka. Berdasarkan kesenjangan ini maka dapat diketahui terpenuhi atau tidaknya harapan konsumen. Kepuasan terjadi ketika harapan-harapan konsumen terpenuhi, dan ketidakpuasan akan terjadi ketika harapan-harapannya tidak terpenuhi. Mahasiswa puas dengan kualitas pendidikan ketika mereka menjalani kehidupan kampus secara positif.

Penelitian ini berfokus pada pengukuran kepuasan pelanggan (mahasiswa). Penelitian ini ditujukan untuk memberikan informasi penting dalam menggambarkan kualitas pelayanan yang diharapkan dan kualitas pelayanan yang diterima oleh mahasiswa. Fokus 
pada pelanggan merupakan unsur pokok dalam penerapan TQM karena penilaian pelanggan akan menjadi parameter kualitas layanan yang diberikan oleh prodi Bisnis Jasa Makanan.

\section{Metode Penelitian}

Penelitian ini menggunakan metode campuran, dengan pendekatan deskriptif yang dilakukan dengan cara mendeskripsikan kembali secara tertulis dari hasil survei lapangan tentang pelayanan yang diberikan oleh program studi Bisnis jasa Makanan pada mahasiswa. Kerangka penelitian menggabungkan hasil survei yang didalami dengan wawancara mendalam terhadap beberapa pihak terkait diharapkan dapat diperoleh gambaran mengenai kepuasan pemangku kepentingan terhadap layanan yang diberikan oleh prodi ini.

Pengumpulan data dilakukan dengan observasi, survei, wawancara, dan analisis dokumen untuk mengumpulkan data. Survei dan wawancara dilakukan pada mahasiswa. Analisis yang dilakukan adalah: (1) Kategorisasi, yakni memilih dan memilah data yang valid atau terukur, kemudian dianalisis dengan menggunakan pendekatan konsep kualitas Layanan; (2) Tabulasi, yakni meyajikan data-data dalam bentuk tabel. Pengujian validitas terhadap instrumen penelitian dengan metode Exploratory factor Analysis (EFA). Item pertanyaan disebut valid jika factor score diatas 0,5.Pengujian konsistensi internal dari instrumen penelitian ini dengan menggunakan metode Cronbach Alpha, instrumen penelitian reliable jika nilai alpha diatas 0,6

\section{Hasil dan Pembahasan}

\subsection{Kualitas Layanan Prodi Bisma}

Pengukuran tingkat kepuasan (kualitas mutu pelayanan pendidikan program studi) dilakukan dengan melakukan perbandingan antara kenyataan atas layanan yang diterima dengan harapan mahasiswa terhadap layanan yang diperolehnya sehingga diperoleh tingkat kesesuaian terhadap pelayanan program studi sebagaimana tabel 3.1.

Tabel 3.1. Uji Paired Sample T-Test Kenyataan Dan Harapan

\begin{tabular}{ccccc}
\hline Variabel dimensi layanan & $\begin{array}{c}\text { Mean } \\
\text { Kenyataan }\end{array}$ & $\begin{array}{c}\text { Mean } \\
\text { Harapan }\end{array}$ & Nilai t & $\begin{array}{c}\text { Sig } \\
\text { (2-tailed) }\end{array}$ \\
\hline Aspek Tangibles & 27.342 & 38.342 & -19.215 & 0.000 \\
\hline Aspek Reliability & 32.257 & 28.571 & -10.763 & 0.000 \\
\hline Aspek Responsiveness & 23.342 & 24.400 & -4.030 & 0.000 \\
\hline Aspek Assurance & 23.514 & 25.457 & -6.453 & 0.000 \\
\hline Aspek Empathy & 24.142 & 25.342 & -3.022 & 0.005 \\
\hline Aspek Information System & 22.174 & 24.257 & -7.392 & 0.000 \\
\hline
\end{tabular}

Sumber: data primer yang diolah (2019)

Tabel 3.1 menunjukan perbedaan rata-rata penilaian responden dalam kenyataan dan harapan pada tingkat taraf kepercayaan sebesar 1 persen. berdasarkan perhitungan statistik dengan uji "t" dalam penelitian diproleh hasil ada kesenjangan antara harapan dan kenyataan layanan yang diharapkan dan layanan yang dirasakan oleh mahasiswa dari 
ke enam aspek. Aspek yang memiliki kesenjangan yang paling tinggi ada pada aspek tangibles dengan nilai " $t$ " sebesar -19.215 , nilai negatif pada nilai " $t$ " mencerminkan bahwa nilai kenyataan lebih kecil dari nilai harapan artinya ada gap atau kesenjangan yang tinggi andara kenyataan dan harapan pada aspek tangibles. Nilai rata-rata antara kenyataan dan harapan untuk aspek tangibles juga memiliki gap yang tinggi dengan nilai rata-rata kenyataan sebesar 27.342 dan nilai rata-rata untuk harapan sebesar 38.342 . sedangkan untuk nilai $t$ terendah terdapat pada Aspek Empathy dengan nilai " $t$ " sebesar 3.022 .

Hasil uji Beda Paired sample t-test dalam penelitian ini konsisten dengan hasil penelitian dengan perhitungan gap yaitu keenam aspek tersebut masih memiliki nilai gap yang negatif. Dengan nilai gap tertinggi terdapa pada aspek tangibles dengan nilai gap sebesar -1.23 lebih besar dibandingkan terhadap kelima aspek yang lainnya. kesimpulan dalam hasil uji Beda Paired sample t-test bahwa semua dari keenam aspek penelitian semuanya signifikan dengan nilai signifikan 1 persen sehingga terdapat perbedaan nilai rata-rata antara kenyataan dan harapan dari keenam aspek penelitian yaitu Aspek Tangibles, Aspek Reliability, Aspek Responsiveness, Aspek Assurance, Aspek Empathy, dan Aspek Information System.

\subsection{Analisis Gap Kualitas Pelayanan Program Studi Bisnis Jasa Makanan}

Analisis kesenjangan digunakan untuk menemukan terjadinya kesenjangan antara harapan mahasiswa terhadap kualitas layanan yang harus diberikan oleh pihak Program Studi Bisnis Jasa Makanan UAD dengan penilaian mahasiswa terhadap kualitas layanan yang telah mereka dapatkan dan mereka rasakan.

Analisis kesenjangan dilakukan pada layanan dosen dalam memberikan, layanan karyawan administrasi dan sistem informasi akademik di Program Studi Bisnis Jasa Makanan UAD. Analisis gap dalam penelitian ini dilakukan 2 hal yaitu analisis per item layanan dan analisis per dimensi layanan dan analisis rerata keseluruhan.

\subsubsection{Analisis Gap Terhadap Kualitas Pelayanan Pendidikan Pada Aspek Tangible (Sarana Pendidikan-Alat Perkuliahan, Media Pengajaran dan Prasarana Pendidikan)}

Dalam dimensi tangibles, dalam tabel 3.2 terlihat bahwa untuk analisis gap per Item semua artribut bernilai negatif, dengan nilai gap tertinggi terdapat pada atribut Fasilitas ibadah yang dapat dipergunakan oleh mahasiswa di Program Studi Bisnis Jasa Makanan dengan nilai gap sebesar -1.77.

Atribut Ruang kuliah sejuk dan nyaman memiliki nilai gap sebesar -1.66 sedangkan untuk nilai gap terendah terdapat pada atribut Ruang kuliah tersedia dengan nilai 0.91. Namun, jika dilihat dimensi gap dengan nilai 1.23 merupakan nilai gap yang tinggi dikarenakan gap antara kenyataan dan harapan lebih dari 1. Hal ini mecerminkan bahwa mahasiswa selama ini merasa bahwa pada aspek tangibles merasakan tidak sesuai dengan apa yang mereka harapkan dengan apa yang mereka terima terutama pada Fasilitas ibadah dan ruang kuliah yang tertata bersi dan rapi. 
Tabel 3.2. Perhitungan Gap Performance-Impormance (Gap P-I) Layanan Pendidikan Kinerja Dosen dalam Proses Pembelajaran pada Aspek Tangibles

\begin{tabular}{|c|c|c|c|c|c|c|c|c|}
\hline Item & $\begin{array}{c}\text { Kenya- } \\
\text { taan }\end{array}$ & $\begin{array}{l}\text { Hara- } \\
\text { pan }\end{array}$ & $\begin{array}{c}\text { Mean } \\
\text { Perfor- } \\
\text { mance }\end{array}$ & $\begin{array}{c}\text { Di- } \\
\text { men- } \\
\text { si }\end{array}$ & $\begin{array}{c}\text { Mean } \\
\text { Impor- } \\
\text { tance }\end{array}$ & $\begin{array}{c}\text { Di- } \\
\text { men- } \\
\text { si }\end{array}$ & Gap & $\begin{array}{c}\text { Di- } \\
\text { men- } \\
\text { si }\end{array}$ \\
\hline $\begin{array}{l}\text { Ketersediaan Ruang } \\
\text { Kuliah }\end{array}$ & 110 & 142 & 3.14 & & 4.06 & & -0.91 & \\
\hline $\begin{array}{l}\text { Ruang Kuliah } \\
\text { Bersih, dan Rapi }\end{array}$ & 115 & 150 & 3.29 & & 4.29 & & -1.00 & \\
\hline $\begin{array}{l}\text { Ruang Kuliah Sejuk } \\
\text { dan Nyaman }\end{array}$ & 93 & 151 & 2.66 & & 4.31 & & -1.66 & \\
\hline $\begin{array}{l}\text { Ketersediaan Sarana } \\
\text { Pembelajaran }\end{array}$ & 116 & 149 & 3.31 & & 4.26 & & -0.94 & \\
\hline $\begin{array}{l}\text { Perpustakaan Yang } \\
\text { Lengkap }\end{array}$ & 105 & 149 & 3.00 & 3.04 & 4.26 & 4.27 & -1.26 & -1.23 \\
\hline $\begin{array}{l}\text { Ketersediaan } \\
\text { Laboratorium }\end{array}$ & 108 & 151 & 3.09 & & 4.31 & & -1.23 & \\
\hline $\begin{array}{l}\text { Ketersediaan Buku } \\
\text { Referensi }\end{array}$ & 111 & 150 & 3.17 & & 4.29 & & -1.11 & \\
\hline $\begin{array}{l}\text { Ketersediaan } \\
\text { Fasilitas Toilet }\end{array}$ & 106 & 148 & 3.03 & & 4.23 & & -1.20 & \\
\hline Fasilitas Ibadah & 93 & 155 & 2.66 & & 4.43 & & -1.77 & \\
\hline
\end{tabular}

Sumber: data primer yang diolah (2019)

\subsubsection{Analisis Gap Mahasiswa Terhadap Kualitas Pelayanan Pendidikan pada Aspek Reliability (Kehandalan Dosen, Staf Akademik)}

Hasil analisis Gap pada aspek Reliability terdapat pada Tabel 3.3. Dalam dimensi Reliability per Item dapat dilihat bahwa dimensi yang memiliki nilai gap tertinggi adalah pada atribut bahan ajar suplemen (handout, modul, dll) yang diberikan kepada mahasiswa untuk melengkapi materi perkuliahan dengan nilai gap sebesar -1.20.

Atribut yang memiliki nilai gap terendah adalah atribut kemampuan staf akademik untuk melayani administrasi kemahasiswaan, Satuan Acara Perkuliahan yang dibuat dosen dan Dosen datang tepat waktu yang sama sama memiliki nilai gap sebesar -0.51. namun jika dilihat pada semua atribut memiliki nilai yang masih minus yang artinya pada aspek Reliability mahasiswa belum merasakan apa yang mereka harapkan. Memberikan atau menyediakan bahan ajaran suplemen kepada mahasiswa diharapkan dilakukan dan diperhatikan agar harapan mahasiswa menjadi kenyataan. 
Tabel 3.3. Perhitungan Gap Performance-Impormance (Gap P-I) Layanan Pendidikan Kinerja Dosen Dalam Proses Pembelajaran Pada Aspek Reliability

\begin{tabular}{|c|c|c|c|c|c|c|}
\hline Item & $\begin{array}{c}\text { Mean } \\
\text { Perfomance }\end{array}$ & Dimensi & $\begin{array}{c}\text { Mean } \\
\text { Perfomance }\end{array}$ & Dimensi & Gap & Dimensi \\
\hline $\begin{array}{l}\text { Kejelasan Materi } \\
\text { Perkuliahan Diberikan } \\
\text { Dosen }\end{array}$ & 3.60 & \multirow{9}{*}{3.58} & 4.26 & \multirow{9}{*}{4.29} & -0.66 & \multirow{9}{*}{-0.70} \\
\hline $\begin{array}{l}\text { Waktu Yang Disediakan } \\
\text { Untuk Diskusi dan } \\
\text { Tanya Jawab }\end{array}$ & 3.66 & & 4.20 & & -0.54 & \\
\hline $\begin{array}{l}\text { Bahan Ajar Suplemen } \\
\text { (Handout, Modul, Dll) } \\
\text { Yang Diberikan Kepada } \\
\text { Mahasiswa Untuk } \\
\text { Melengkapi Materi } \\
\text { Perkuliahan }\end{array}$ & 3.20 & & 4.40 & & -1.20 & \\
\hline $\begin{array}{l}\text { Dosen Mengembalikan } \\
\text { Hasil Ujian/Tugas } \\
\text { Dengan Nilai Yang } \\
\text { Obyektif. }\end{array}$ & 3.89 & & 4.57 & & -0.69 & \\
\hline $\begin{array}{l}\text { Dosen Datang Tepat } \\
\text { Waktu }\end{array}$ & 3.49 & & 4.00 & & -0.51 & \\
\hline $\begin{array}{l}\text { Dosen Memadai Sesuai } \\
\text { Dengan Bidang } \\
\text { Keahliannya }\end{array}$ & 3.63 & & 4.37 & & -0.74 & \\
\hline $\begin{array}{l}\text { Satuan Acara } \\
\text { Perkuliahan Yang Dibuat } \\
\text { Dosen }\end{array}$ & 3.66 & & 4.17 & & -0.51 & \\
\hline $\begin{array}{l}\text { Kemampuan Staf } \\
\text { Akademik Untuk } \\
\text { Melayani Administrasi } \\
\text { Kemahasiswaan }\end{array}$ & 3.77 & & 4.29 & & -0.51 & \\
\hline $\begin{array}{l}\text { Kualitas Layanan Staf } \\
\text { Akademik Untuk } \\
\text { Memenuhi Kepentingan } \\
\text { Mahasiswa }\end{array}$ & 3.37 & & 4.31 & & -0.94 & \\
\hline
\end{tabular}

Sumber: data primer yang diolah (2019)

\subsubsection{Analisis Gap Mahasiswa Terhadap Kualitas Pelayanan Pendidikan pada Aspek Responsiveness (Sikap Tanggap)}

Tabel 3.4 menunjukan bahwa dimensi gap sebesar -0.18 yang artinya bahwa pada aspek Responsiveness dari harapan dan kenyataan yang dirasakan oleh mahasiswa sudah hampir sama. Atribut yang paling kecil nilai dimensi gapnya adalah Program Studi Bisnis Jasa Makanan memberikan bantuan pengobatan bagi mahasiswa yang sakit dan Program Studi Bisnis Jasa Makanan menyediakan beasiswa bagi mahasiswa yang tidak mampu dengan nilai yang sama yaitu -0.11. Menurut mahasiswa Program Studi Bisnis Jasa 
Makanan hampir memberikan pelayanan pada aspek Responsiveness sesuai dengan harapan yang mereka inginkan. Sedangkan untuk atribut yang memiliki dimensi nilai gap tertinggi adalah Program Studi Bisnis Jasa Makanan membantu mahasiswa apabila menghadapi masalah akademik dengan nilai sebesar -0.26. yang artinya bahwa Program Studi Bisnis Jasa Makanan harus menyediakan atau memberi pengarahan terhadap dosen bimbingan akademis untuk lebih memperhatikan keluhan atau masalah akademik yang dihadapi oleh mahasiswa.

Tabel 3.4. Perhitungan Gap Performance-Impormance (Gap P-I) Layanan Pendidikan Kinerja Dosen dalam Proses Pembelajaran pada Aspek Responsiveness

\begin{tabular}{|c|c|c|c|c|c|c|}
\hline Item & $\begin{array}{c}\text { Mean } \\
\text { Perfomance }\end{array}$ & Dimensi & $\begin{array}{c}\text { Mean } \\
\text { Perfomance }\end{array}$ & Dimensi & Gap & Dimensi \\
\hline $\begin{array}{l}\text { Program Studi Bisma } \\
\text { menyediakan dosen } \\
\text { Bimbingan Konseling } \\
\text { bagi mahasiswa }\end{array}$ & 4.11 & & 4.29 & & -0.17 & \\
\hline $\begin{array}{l}\text { Program Studi Bisma } \\
\text { menyediakan beasiswa } \\
\text { bagi mahasiswa yang } \\
\text { tidak mampu }\end{array}$ & 4.00 & & 4.11 & & -0.11 & \\
\hline $\begin{array}{l}\text { Program Studi Bisma } \\
\text { membantu mahasiswa } \\
\text { apabila menghadapi } \\
\text { masalah akademik }\end{array}$ & 3.77 & & 4.03 & & -0.26 & \\
\hline $\begin{array}{l}\text { Program Studi Bisma } \\
\text { beserta jajarannya } \\
\text { menyediakan waktu } \\
\text { bagi orang tua } \\
\text { mahasiswa untuk } \\
\text { berkonsultasi }\end{array}$ & 4.00 & 3.89 & 4.20 & 4.07 & -0.20 & -0.18 \\
\hline $\begin{array}{l}\text { Program Studi Bisma } \\
\text { memberikan bantuan } \\
\text { pengobatan bagi } \\
\text { mahasiswa yang sakit }\end{array}$ & 3.60 & & 3.71 & & -0.11 & \\
\hline $\begin{array}{l}\text { Program Studi Bisma } \\
\text { memberikan bantuan } \\
\text { asuransi bagi } \\
\text { mahasiswa yang } \\
\text { mendapatkan musibah } \\
\text { kecelakaan }\end{array}$ & 3.86 & & 4.06 & & -0.20 & \\
\hline
\end{tabular}

Sumber: data primer yang diolah (2019)

\subsubsection{Analisis Gap Mahasiswa Terhadap Kualitas Pelayanan Pendidikan pada Aspek Assurance (Perlakuan pada Mahasiswa)}

Pada aspek Assurance (Tabel 3.5) nilai gap tertinggi adalah pada atribut Sanksi bagi mahasiswa yang melanggar peraturan yang telah ditetapkan Program Studi Bisnis Jasa 
Makanan dan berlaku untuk semua mahasiswa tanpa terkecuali dengan nilai sebesar 0.91 .

Tabel 3.5. Perhitungan Gap Performance-Impormance (Gap P-I) Layanan Pendidikan Kinerja Dosen dalam Proses Pembelajaran pada Aspek Assurance

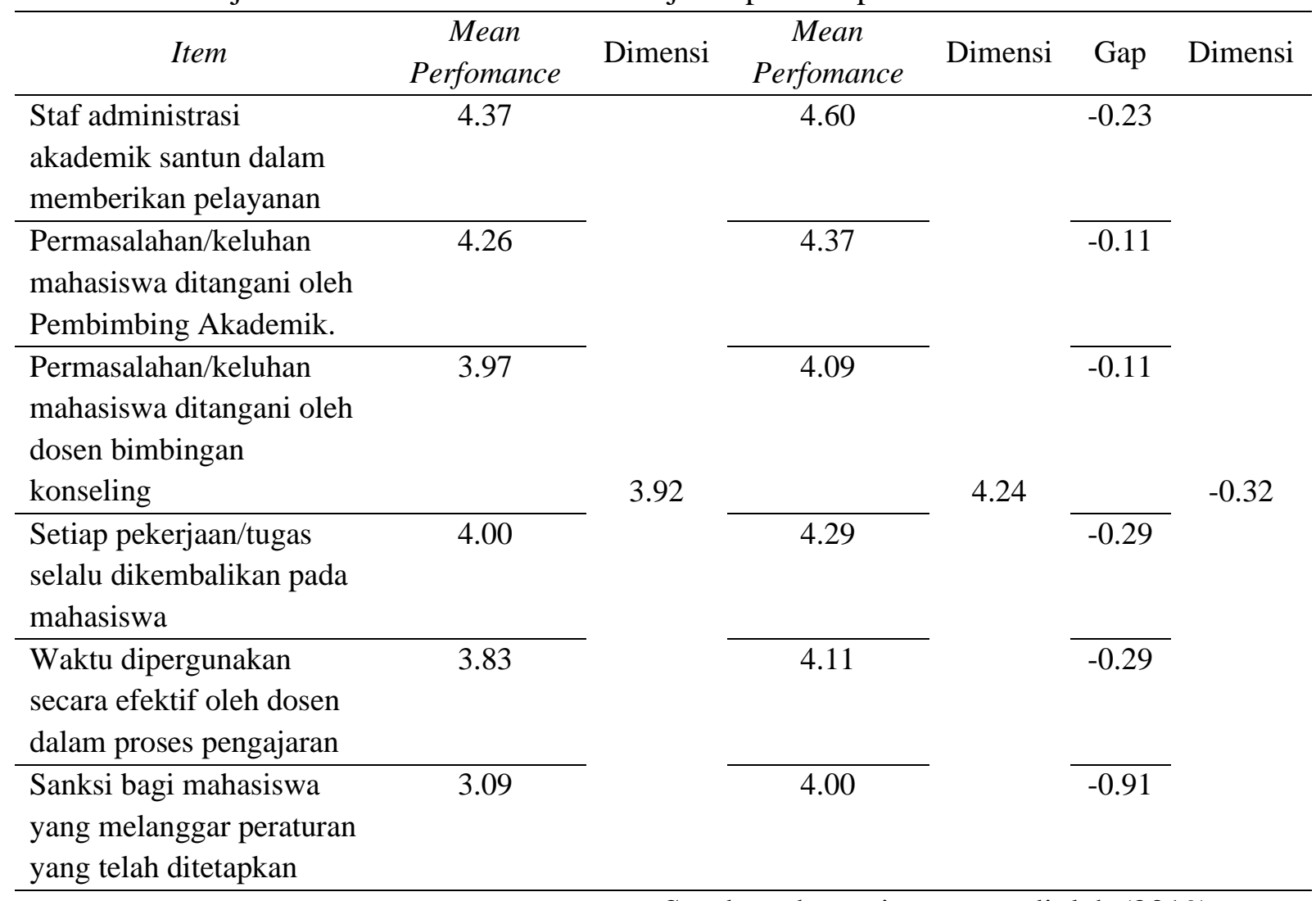

Menurut mahasiswa jika ada pelangaran yang dilakukan oleh mahasiswa seperti titip absensi atau melakukan contekan saat ulangan Program Studi Bisnis Jasa Makanan tidak memberikan sanksi atau hukuman yang diberikan tidak berlaku untuk semua mahasiswa ada pengecualian hal ini lah yang memberikan nilai pada atribut tersebut tinggi. Diharapkan Program Studi Bisnis Jasa Makanan lebih tegas lagi dalam pemberian sanksi atau hukuman pada semua mahasiswa yang melakukan kesalahan atau melanggar aturan yang telah ditetapkan sehingga harapan dan kenyataan memiliki Gap yang semakin kecil. 3.2.5. Analisis Gap Mahasiswa Terhadap Kualitas Pelayanan Pendidikan pada Aspek Empathy (pemahaman terhadap kepentingan mahasiswa)

Hasil Analisis Gap terhadap Aspek Emphaty tampak pada tabel 3.6. Pada aspek empathy nilai dimensi gap sebesar -0.20 dan nilai gap pada semua atribut bernilainegatif yang artinya pada aspek empathy apa yang telah didapatkan dan dirasakan olah mahasiswa belum sesuai dengan harapan mahasiswa.

Pada aspek empathy atribut yang memiliki nilai gap tertinggi adalah besarnya kontribusi biaya (sumbangan pengembangan lembaga) dibicarakan dengan orang tua wali mahasiswa dengan nilai -0.46 yang artinya menurut mahasiswa bahwa keterbukaan dan rincian biaya yang dikeluarkan oleh wali mahasiswa tidak dijelaskan secara rinci oleh Program Studi Bisnis Jasa Makanan. Namun pada atribut Dosen bersedia membantu 
mahasiswa yang mengalami kesulitan bidang akademik/mata kuliah merupakan satu satunya atribut yang tidak memiliki gap (0.00) yang artinya pada atribut ini mahasiswa merasakan bahwa kenyataan dan harapan mahasiswa sudah sesuai.

Tabel 3.6. Perhitungan Gap Performance-Impormance (Gap P-I) Layanan Pendidikan Kinerja Dosen Dalam Proses Pembelajaran pada Aspek Empathy

\begin{tabular}{|c|c|c|c|c|c|c|}
\hline Item & $\begin{array}{c}\text { Mean } \\
\text { Perfomance }\end{array}$ & Dimensi & $\begin{array}{c}\text { Mean } \\
\text { Perfomance }\end{array}$ & Dimensi & Gap & Dimensi \\
\hline $\begin{array}{l}\text { Kepedulian dalam } \\
\text { memahami kepentingan } \\
\text { dan kesulitan mahasiswa }\end{array}$ & 4.03 & & 4.40 & & -0.37 & \\
\hline $\begin{array}{l}\text { Besarnya kontribusi } \\
\text { biaya (sumbangan } \\
\text { pengembangan lembaga) } \\
\text { dibicarakan dengan } \\
\text { orang tua wali } \\
\text { mahasiswa }\end{array}$ & 4.09 & & 4.54 & & -0.46 & \\
\hline $\begin{array}{l}\text { Program Studi Bisnis } \\
\text { Jasa Makanan } \\
\text { memonitor terhadap } \\
\text { kemajuan mahasiswa }\end{array}$ & 4.06 & & 4.20 & & -0.14 & \\
\hline $\begin{array}{l}\text { Dosen bersedia } \\
\text { membantu mahasiswa } \\
\text { yang mengalami } \\
\text { kesulitan bidang } \\
\text { akademik }\end{array}$ & 4.03 & 4.02 & 4.03 & 4.22 & 0.00 & -0.20 \\
\hline $\begin{array}{l}\text { Dosen bersikap terbuka, } \\
\text { kooperatif dengan } \\
\text { mahasiswa }\end{array}$ & 3.83 & & 3.86 & & -0.03 & \\
\hline $\begin{array}{l}\text { Program Studi Bisnis } \\
\text { Jasa Makanan berusaha } \\
\text { memahami minat dan } \\
\text { bakat mahasiswa dan } \\
\text { berusaha untuk } \\
\text { mengembangkannya }\end{array}$ & 4.11 & & 4.31 & & -0.20 & \\
\hline
\end{tabular}

Sumber: data primer yang diolah (2019)

\subsubsection{Analisis Gap Aspek Information System}

Sistem Informasi menjadi sarana yang sangat diperhatikan di UAD. Sarana ini disediakan untuk membantu mahasiswa dalam rangka menyelesaikan masalah administrasi, baik administrasi akademik maupun administrasi kemahasiswaan. Selain itu sarana ini juga dapat digunakan oleh semua pihak yang terkait, termasuk mahasiswa untuk mengakses informasi. Hasil Analisis Gap terhadap Aspek Sistem informasi tampak pada tabel 3.7.

Pada tabel 3.7 aspek Information System memiliki nilai dimensi gap sebesar -0.35. pada aspek Information System terdapat atribut yang sudah memnuhi harapan mahasiswa 
yaitu atribut Program Studi Bisnis Jasa Makanan berusaha memberikan respon positif setiap pengaduan mahasiswa dan Program Studi ini memberikan informasi sistem perkuliahan dalam bentuk buku panduan perkuliahan yang tidak memiliki gap.

Tabel 3.7. Perhitungan Gap Performance-Impormance (Gap P-I) Layanan Pendidikan Kinerja Dosen dalam Proses Pembelajaran pada Aspek Information System

\begin{tabular}{|c|c|c|c|c|c|c|}
\hline Item & $\begin{array}{c}\text { Mean } \\
\text { Perfomance }\end{array}$ & Dimensi & $\begin{array}{c}\text { Mean } \\
\text { Perfomance }\end{array}$ & Dimensi & GAP & Dimensi \\
\hline $\begin{array}{l}\text { Memberikan informasi } \\
\text { sistem perkuliahan } \\
\text { dalam bentuk buku } \\
\text { panduan perkuliahan }\end{array}$ & 3.83 & & 3.83 & & 0.00 & \\
\hline $\begin{array}{l}\text { Memberikan informasi } \\
\text { akademik dan pelayanan } \\
\text { non akademik dalam } \\
\text { bentuk website }\end{array}$ & 3.51 & & 4.06 & & -0.54 & \\
\hline $\begin{array}{l}\text { Memberikan informasi } \\
\text { dan pelayanan baik }\end{array}$ & 3.89 & & 4.11 & & -0.23 & \\
\hline $\begin{array}{l}\text { akademik maupun non } \\
\text { akademi }\end{array}$ & & 3.70 & & 4.04 & & -0.35 \\
\hline $\begin{array}{l}\text { Membuka layanan } \\
\text { pengaduan bagi } \\
\text { mahasiswa yang } \\
\text { memiliki permasalahan }\end{array}$ & 3.60 & & 4.00 & & -0.40 & \\
\hline $\begin{array}{l}\text { Memberikan respon } \\
\text { positif setiap pengaduan } \\
\text { mahasiswa }\end{array}$ & 3.74 & & 3.74 & & 0.00 & \\
\hline $\begin{array}{l}\text { Menjelaskan penggunaan } \\
\text { dana kemahasiswaan }\end{array}$ & 3.60 & & 4.51 & & -0.91 & \\
\hline
\end{tabular}

Sumber: data primer diolah (2019).

\subsection{Importance-Performance Analysis (IPA)}

\subsubsection{Analisis Importance-Performance Analysis (IPA) Aspek Tangibles}

Hasil analisis kepuasan mahasiswa dengan menggunakan metode IPA terhadap aspek tangibles tampak pada gambar 3.1. Gambar 3.1 menunjukan bahwa dua (2) atribut terdapat pada Kuadran A, empat (4) di kuadran B, dua (2) di kuadran C, dan satu (1) berada pada kuadran D. Kuadran A adalah prioritas utama dimana mahasiswa sebagai responden merasakan atribut tersebut sangat penting dan mempunyai harapan tinggi namun belum merasakan kinerja yang maksimal. Adapun atribut tersebut:

1. (5) Prodi Bisma mempunyai perpustakaan yang lengkap

2. (9) Fasilitas ibadah yang dapat dipergunakan oleh mahasiswa di Program Studi Bisnis Jasa Makanan 


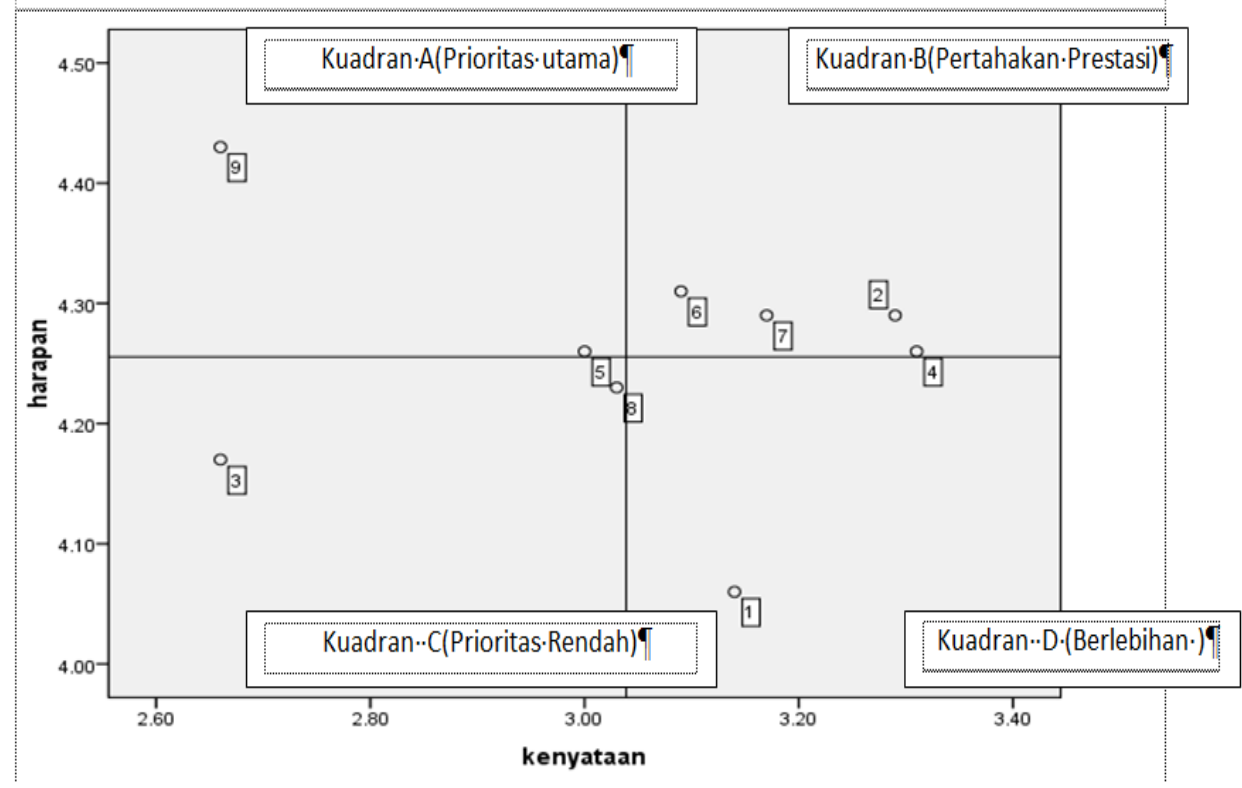

Gambar 3.1. Diagram Kartesius Aspek Tangibles

Sumber: Data Primer yang Diolah (2019)

Kuadran B menunjukan keberadaan keberadaan atribut layanan yang juga dianggap penting oleh mahasiswa dan kinerjanya sudah dianggap baik oleh mahasiswa, oleh Program Studi Bisnis Jasa Makanan karenanya harus memepertahankan kinerja atribut ini supaya dapat terus menjadi lebih baik dan terus memenuhi apa yang menjadi harapan mahasiswa dan diharapkan juga dapat menjadi kekuatan program studi sebagai proses positive word of mouth. Hasil analisis menunjukan adanya empat atribut yaitu:

1. (2) Ruang kuliah tertata dengan bersih, dan rapi

2. (4) Sarana pembelajaran yang tersedia di ruang kuliah.

3. (6) Prodi Bisma mempunyai Laboratorium yang relevan dengan kebutuhan keilmuan bagi mahasiswa

4. (7) Ketersediaan buku referensi yang di perpustakaan

Kuadran $\mathrm{C}$ memuat atribut-atribut layanan yang bagi mahasiswa tidak terlalu diharapkan sehingga tingkat kepentingannya tidak mendapat penilaian tinggi dan kinerjanya juga nilai biasa-biasa saja, sehingga Program Studi tidak harus memberikan fokus perbaikan untuk atribut layanan yang ada dalam kuadran ini. Berikut atribut yang berada dalam kuadran ini:

1. (3) Ruang kuliah sejuk dan nyaman

2. (8) Ketersediaan fasilitas kamar kecil yang cukup dan bersih

Kuadran D menunjukan keberadaan atribut layanan yang menurut mahasiswa kinerjanya sudah baik bahkan cenderung melebihi apa yang diingikan mahasiswa karena sebenarnya mahasiswa tidak terlalu mempunyai harapan pada atribut layanan ini, sehingga tidak perlu memeberikan fokus pada atribut yang berada dalam kuadran D. Atribut yang berada dalam kuadran D ini adalah

(1) Ruang kuliah tersedia. 


\subsubsection{Analisis Importance-Performance Analysis (IPA) Aspek Reliability}

Hasil analisis kepuasan mahasiswa dengan menggunakan metode IPA terhadap aspek Reliabilities tampak pada gambar 3.2.

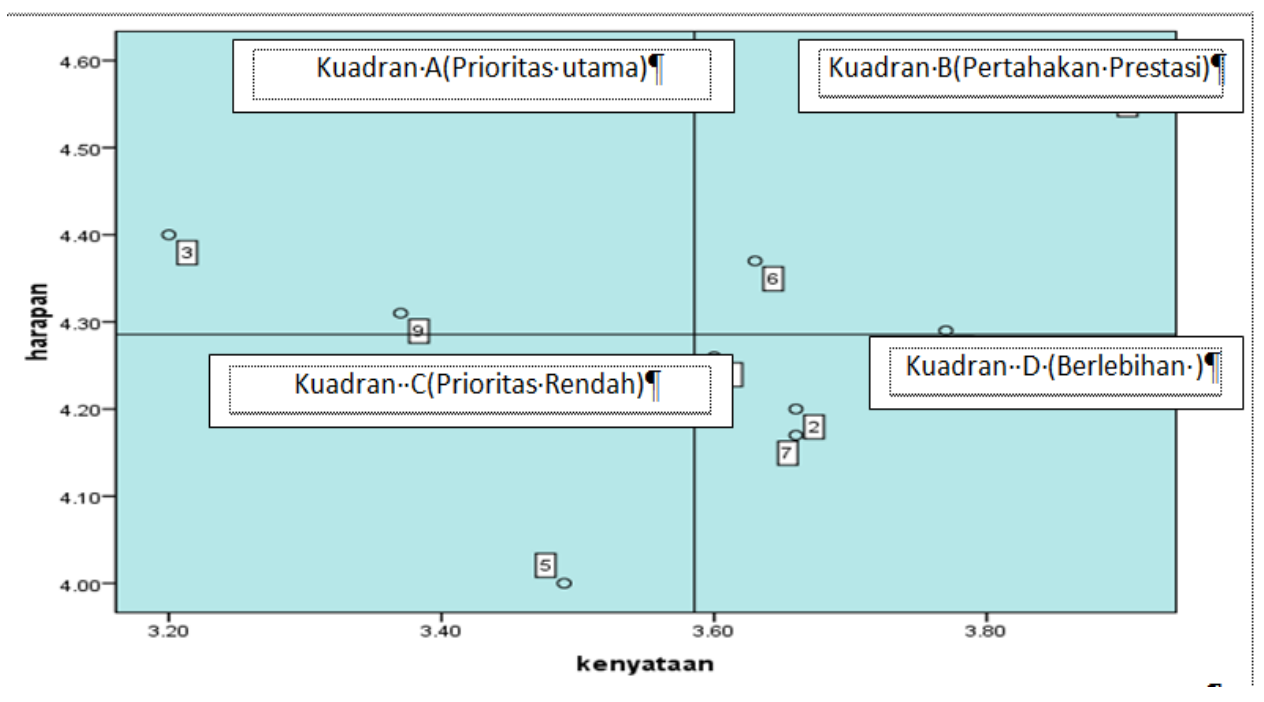

Gambar 3.2. Diagram Kartesius Aspek Reliability

Sumber: data primer yang diolah (2019)

Gambar 3.2 menunjukan bahwa dua (2) atribut terdapat pada Kuadran A, tiga (3) di kuadran B, satu (1) di kuadran C, dan tiga (3) berada pada kuadran D. Kuadran A adalah prioritas utama dimana mahasiswa sebagai responden merasakan atribut tersebut sangat penting dan mempunyai harapan tinggi namun belum merasakan kinerja yang maksimal. Adapun atribut tersebut:

1. (3) Bahan ajar suplemen (handout, modul, dll) yang diberikan kepada mahasiswa untuk melengkapi materi perkuliahan

2. (9) Kualitas layanan staf akademik untuk memenuhi kepentingan mahasiswa

Kuadran B menunjukan keberadaan atribut layanan yang juga dianggap penting oleh mahasiswa dan kinerjanya sudah dianggap baik oleh mahasiswa, maka Program Studi Bisnis Jasa Makanan harus mempertahankan kinerja atribut ini supaya dapat terus menjadi lebih baik dan terus memenuhi apa yang menjadi harapan mahasiswa dan diharapkan juga dapat menjadi kekuatan program studi sebagai proses positif word of mouth. Hasil analisis menunjukan adanya tiga atribut yaitu:

1. (6) Dosen memadai sesuai dengan bidang keahliannya

2. (8) Kemampuan staf akademik untuk melayani administrasi kemahasiswaan

3. (4 ) Dosen mengembalikan hasil ujian/tugas dengan nilai yang obyektif.

Atribut-atribut layanan yang berada dalam kuadran $\mathrm{C}$ adalah mahasiswa tidakmempunyai harapan terlalu tinggi sehingga tingkat kepentingannya tidak mendapat penilaian tinggi dan kinerjanya juga nilai biasa-biasa saja, sehingga Program Studi tidak harus memberikan fokus perbaikan untuk atribut layanan yang ada dalam kuadran ini. Atribut yang berada dalam kuadran ini adalah

(5) Dosen datang tepat waktu. 
Kuadran D menunjukan keberadaan atribut layanan yang menurut mahasiswa kinerjanya sudah baik bahkan cenderung melebihi apa yang diingikan mahasiswa karena sebenarnya mahasiswa tidak terlalu mempunyai harapan pada atribut layanan ini, sehingga tidak perlu memeberikan fokus pada atribut yang berada dalam kuadran D. Atribut yang berada dalam kuadran D ini adalah sebagai berikut:

1. (1) Kejelasan materi perkuliahan diberikan dosen

2. (2) Waktu yang disediakan untuk diskusi dan tanya jawab

3. (7) Satuan Acara Perkuliahan yang dibuat dosen

\subsubsection{Analisis Importance-Performance Analysis (IPA) Aspek Assurance}

Hasil analisis kepuasan mahasiswa dengan menggunakan metode IPA terhadap aspek tangibles tampak pada gambar 3.3. Dari gambar 3.3 menunjukan bahwa tidak terdapat atribut pada Kuadran A, tiga (3) di kuadran B, satu (1) di kuadran C, dan dua (2) berada di kuadran D.

Kuadran A adalah prioritas utama dimana mahasiswa sebagai responden merasakan atribut tersebut sangat penting dan mempunyai harapan tinggi namun belum merasakan kinerja yang maksimal. Dalam aspek ini tidak ada atribut yang berada pada kuadrat $\mathrm{A}$ sehingga dapat dikatakan bakwa tidak terdapat atribut penting namun belum mendapatkan hasil yang tinggi.

Kuadran B menunjukan keberadaan keberadaan atribut layanan yang juga dianggap penting oleh mahasiswa dan kinerjanya sudah dianggap baik oleh mahasiswa, oleh Program Studi Bisnis Jasa Makanan karenanya harus memepertahankan kinerja atribut ini supaya dapat terus menjadi lebih baik dan terus memenuhi apa yang menjadi harapan mahasiswa dan diharapkan juga dapat menjadi kekuatan program studi sebagai proses positive word of mouth. Hasil analisis menunjukan adanya empat atribut yaitu

1. Program Studi Bisnis Jasa Makanan didkung staf administrasi akademik yang baik

2. Program Studi Bisnis Jasa Makanan memberikan bimbingan akademik yang memadai

3. Program Studi Bisnis Jasa Makanan mengembalikan pekerjaan/tugas kepada mahasiswa

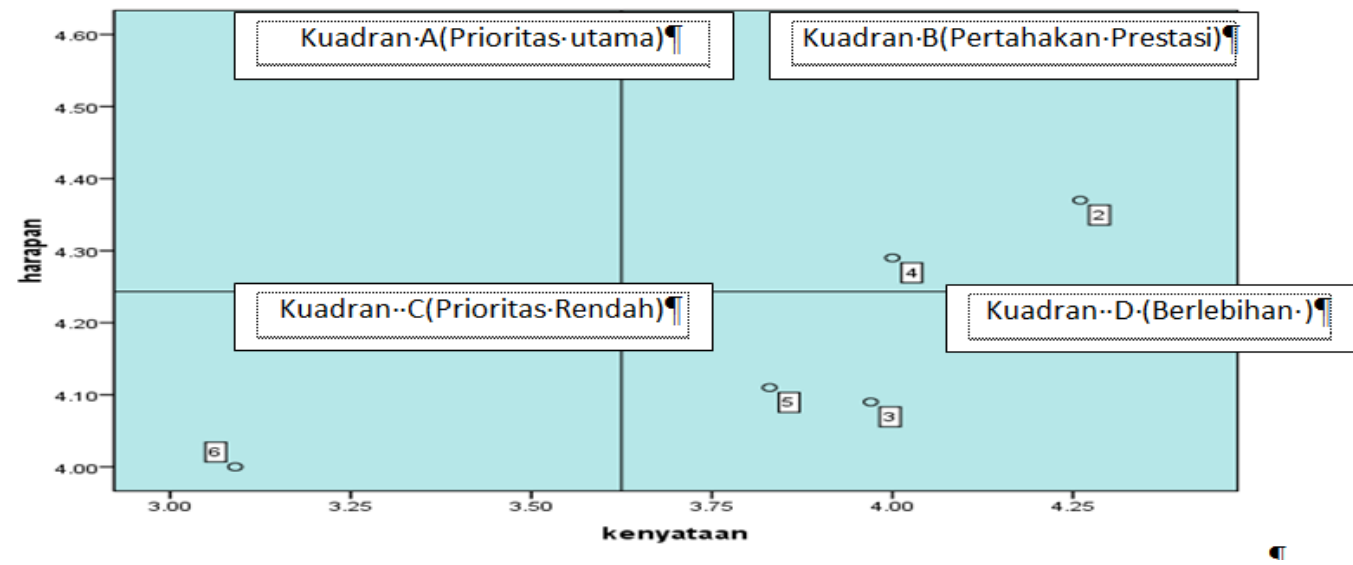

Gambar 3.3. Diagram Kartesius Aspek Assurance

Sumber: Data Primer Yang Diolah (2019) 
Atribut-atribut layanan yang berada dalam kuadran $\mathrm{C}$ adalah mahasiswa tidak mempunyai harapan terlalu tinggi sehingga tingkat kepentingannya tidak mendapat penilaian tinggi dan kinerjanya juga nilai biasa-biasa saja, sehingga Program Studi tidak harus memberikan fokus perbaikan untuk atribut layanan yang ada dalam kuadran ini. Berikut atributyang berada dalam kuadran ini:

1. (6) Program Studi Bisnis Jasa Makanan memberikan sangsi kepada mahasiswa yang tidak mengerjakan tugas secara proporsional.

Kuadran D menunjukan keberadaan atribut layanan yang menurut mahasiswa kinerjanya sudah baik bahkan cenderung melebihi apa yang diingikan mahasiswa karena sebenarnya mahasiswa tidak terlalu mempunyai harapan pada atribut layanan ini, sehingga tidak perlu memberikan fokus pada atribut yang berada dalam kuadran D. Atribut yang berada dalam kuadran D ini adalah sebagai berikut:

1. (3) Program Studi Bisnis Jasa Makanan membantu mahasiswa apabila menghadapi masalah akademik

2. (5) Dosen menggunakan waktu kuliah secara efektif

\subsubsection{Analisis Importance-performance Analysis (IPA) Aspek Responsiveness}

Hasil analisis kepuasan mahasiswa dengan menggunakan metode IPA terhadap aspek tangibles tampak pada gambar 3.4. Dari gambar 3.4 menunjukan bahwa tidak terdapat atribut pada Kuadran A, tiga (3) di kuadran B, satu (1) di kuadran C, dan dua (2) berada pada kuadran D.

Kuadran B menunjukan keberadaan keberadaan atribut layanan yang juga dianggap penting oleh mahasiswa dan kinerjanya sudah dianggap baik oleh mahasiswa, oleh Program Studi Bisnis Jasa Makanan karenanya harus memepertahankan kinerja atribut ini supaya dapat terus menjadi lebih baik dan terus memenuhi apa yang menjadi harapan mahasiswa dan diharapkan juga dapat menjadi kekuatan program studi sebagai proses positive word of mouth. Hasil analisis menunjukan adanya empat atribut yaitu:

1. (1) Program Studi Bisnis Jasa Makanan menyediakan bimbingan dan konseling pada mahasiswa.

2. (2) Program Studi Bisnis Jasa Makanan menyediakan beasiswa kepada mahasiswa yang tidak mampu

3. (4) Program Studi Bisnis Jasa Makanan menyediakan waktu bagi orang tua mahasiswa untuk berkonsultasi mengenai mahasiswa.

Atribut-atribut layanan yang berada dalam kuadran $\mathrm{C}$ adalah mahasiswa tidak mempunyai harapan terlalu tinggi sehingga tingkat kepentingannya tidak mendapat penilaian tinggi dan kinerjanya juga nilai biasa-biasa saja, sehingga Program Studi tidak harus memberikan fokus perbaikan untuk atribut layanan yang ada dalam kuadran ini. Berikut atribut yang berada dalam kuadran ini adalah:

1. (5) Program Studi Bisnis Jasa Makanan memberikan engobatan kepada mahasiswa 


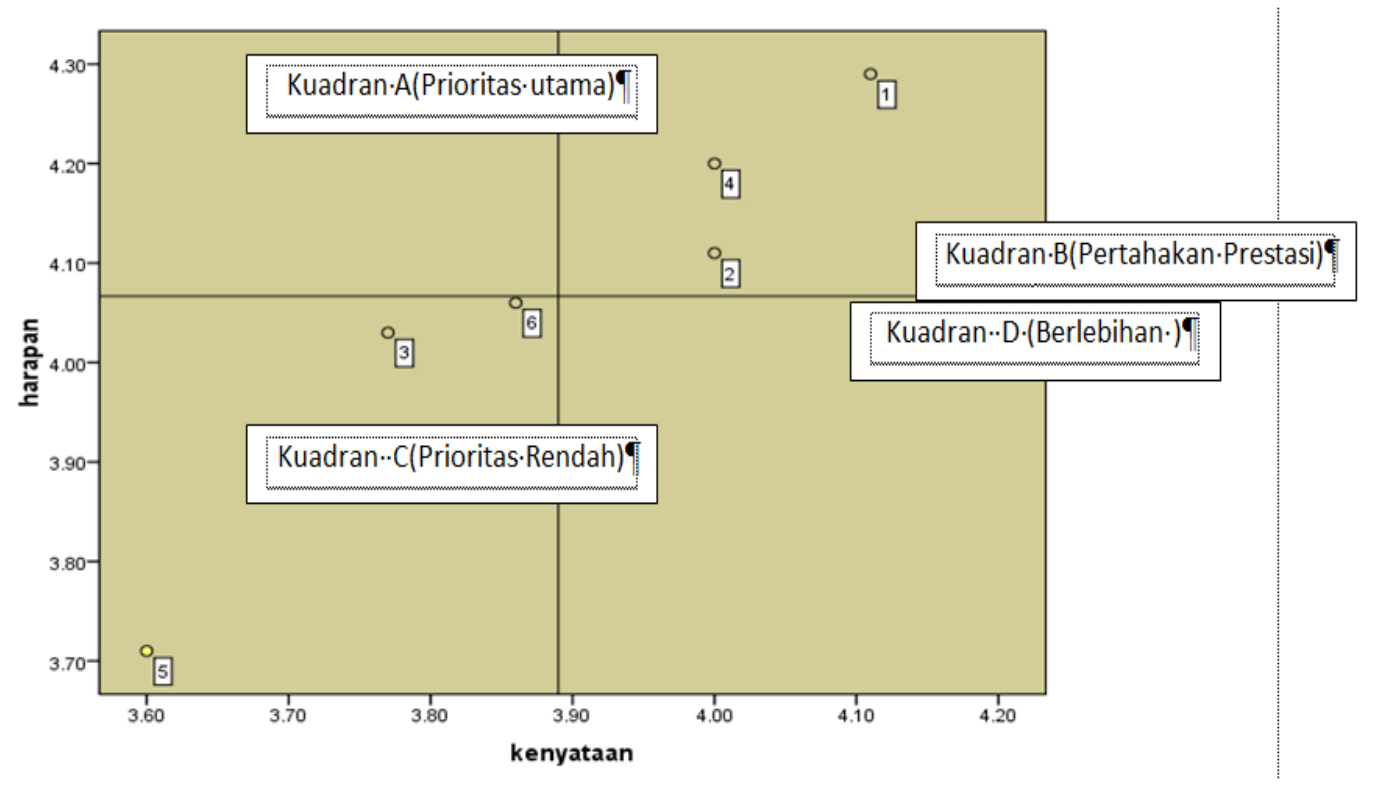

Gambar 3.4. Diagram Kartesius Aspek Responsiveness

Sumber: data primer yang diolah (2019)

Kuadran D menunjukan keberadaan atribut layanan yang menurut mahasiswa kinerjanya sudah baik bahkan cenderung melebihi apa yang diingikan mahasiswa karena sebenarnya mahasiswa tidak terlalu mempunyai harapan pada atribut layanan ini, sehingga tidak perlu memeberikan fokus pada atribut yang berada dalam kuadran D. Atribut yang berada dalam kuadran D ini adalah sebagai berikut:

1. (3) Program Studi Bisnis Jasa Makanan memberikan bimbinganakademik bagi mahasiswa

2. (6) Program Studi Bisnis Jasa Makanan memberikan asuransi bagi mahasiswa yang mengalami kecelakaan

\subsubsection{Analisis Importance-performance Analysis (IPA) Aspek Emphaty}

Hasil analisis kepuasan mahasiswa dengan menggunakan metode IPA terhadap aspek emphaty tampak pada gambar 3.5. Dari gambar 3.5 menunjukan bahwa tidak terdapat atribut pada Kuadran A, dua (2) di kuadran B, satu (1) di kuadran C, dan (2) atribut berada pada kuadran D.

Kuadran B menunjukan keberadaan keberadaan atribut layanan yang juga dianggap penting oleh mahasiswa dan kinerjanya sudah dianggap baik oleh mahasiswa, oleh Program Studi Bisnis Jasa Makanan karenanya harus memepertahankan kinerja atribut ini supaya dapat terus menjadi lebih baik dan terus memenuhi apa yang menjadi harapan mahasiswa dan diharapkan juga dapat menjadi kekuatan program studi sebagai proses positive word of mouth. Hasil analisis menunjukan adanya empat atribut yaitu:

1. (1) Program Studi Bisnis Jasa Makanan membantu mahasiswa yang mengalami kesulitan

2. (6) Program Studi Bisnis Jasa Makanan membantu mahasiswa dalam mengembangkan minat dan bakat mereka 


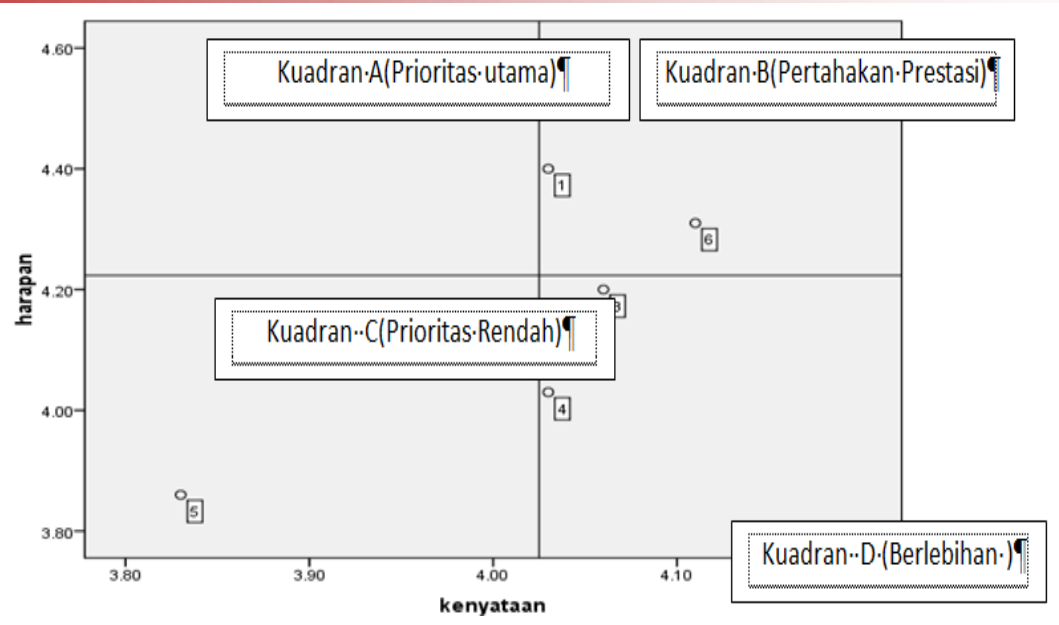

Gambar 3.5. Diagram Kartesius Aspek Empathy

Sumber: Data Primer yang Diolah (2019)

Atribut-atribut layanan yang berada dalam kuadran $\mathrm{C}$ adalah mahasiswa tidak mempunyai harapan terlalu tinggi sehingga tingkat kepentingannya tidak mendapat penilaian tinggi dan kinerjanya juga nilai biasa-biasa saja, sehingga Program Studi tidak harus memberikan fokus perbaikan untuk atribut layanan yang ada dalam kuadran ini. Berikut atribut yang berada dalam kuadran C:

1. (5) Dosen Program Studi Bisnis Jasa Makanan bersikap terbuka dan kooperatif kepada mahasiswa

Kuadran D menunjukkan keberadaan atribut layanan yang menurut mahasiswa kinerjanya sudah baik bahkan cenderung melebihi apa yang diingikan mahasiswa karena sebenarnya mahasiswa tidak terlalu mempunyai harapan pada atribut layanan ini, sehingga tidak perlu memeberikan fokus pada atribut yang berada dalam kuadran D. Atribut yang berada dalam kuadran D ini adalah sebagai berikut:

1. (3) Program Studi Bisnis Jasa Makanan memonitor terhadap kemajuan mahasiswa melalui dosen Pembimbing Akademik atau dosen bimbingan konseling

2. (4) Dosen bersedia membantu mahasiswa yang mengalami kesulitan bidang akademik/mata kuliah

\subsubsection{Analisis Importance-performance Analysis (IPA) Aspek Information System}

Hasil analisis kepuasan mahasiswa dengan menggunakan metode IPA terhadap aspek tangibles tampak pada gambar 3.6. Gambar 3.6 menunjukan bahwa dua (2) atribut terdapat pada Kuadran A, satu (1) di kuadran B, satu (1) di kuadran C, dan dua (2) berada pada kuadran D. Kuadran A adalah prioritas utama dimana mahasiswa sebagai responden merasakan atribut tersebut sangat penting dan mempunyai harapan tinggi namun belum merasakan kinerja yang maksimal. Adapun atribut tersebut:

1. (2) Program Studi Bisnis Jasa Makanan memberikan informasi akademik dan pelayanan non akademik dalam bentuk website

2. (6) Program Studi Bisnis Jasa Makanan secara transparan dalam menjelaskan penggunaan dana kemahasiswaan 


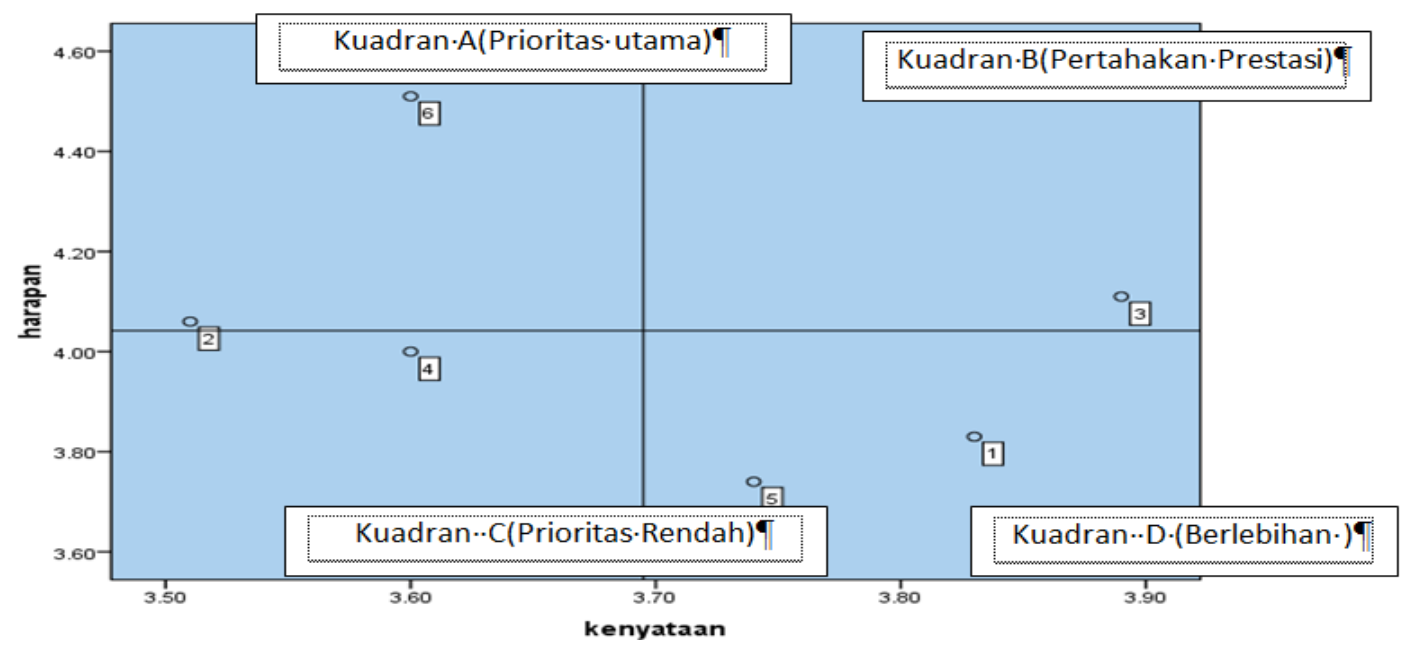

Gambar 3.6. Diagram Kartesius Aspek Information System

Sumber: data primer yang diolah (2019)

Kuadran B menunjukan keberadaan keberadaan atribut layanan yang juga dianggap penting oleh mahasiswa dan kinerjanya sudah dianggap baik oleh mahasiswa, oleh karenanya Program Studi Bisnis Jasa Makanan harus memepertahankan kinerja atribut ini supaya dapat terus menjadi lebih baik dan terus memenuhi apa yang menjadi harapan mahasiswa dan diharapkan juga dapat menjadi kekuatan program studi sebagai proses positive word of mouth. Hasil analisis menunjukkan atribut yang berada di kuadran B adalah atribut

1. (3) Program Studi Bisnis Jasa Makanan secara terbuka memberikan informasi dan pelayanan baik akademik maupun non akademik

Atribut-atribut layanan yang berada dalam kuadran $\mathrm{C}$ adalah mahasiswa tidak mempunyai harapan terlalu tinggi sehingga tingkat kepentingannya tidak mendapat penilaian tinggi dan kinerjanya juga nilai biasa-biasa saja, sehingga Program Studi tidak harus memberikan fokus perbaikan untuk atribut layanan yang ada dalam kuadran ini. Berikut atribut dalam kuadran ini:

1. (4) Program Studi Bisnis Jasa Makanan membuka layanan pengaduan bagi mahasiswa yang memiliki permasalahan

Kuadran D menunjukan keberadaan atribut layanan yang menurut mahasiswa kinerjanya sudah baik bahkan cenderung melebihi apa yang diingikan mahasiswa karena sebenarnya mahasiswa tidak terlalu mempunyai harapan pada atribut layanan ini, sehingga tidak perlu memeberikan fokus pada atribut yang berada dalam kuadran D. Atribut yang berada dalam kuadran D ini adalah:

1. (1) Program Studi Bisnis Jasa Makanan memberikan informasi sistem perkuliahan dalam bentuk buku panduan perkuliahan

2. (5) Program Studi Bisnis Jasa Makanan berusaha memberikan respons positif setiap pengaduan mahasiswa. 


\subsubsection{Analisis Importance-Performance Analysis (IPA) Semua Aspek}

Untuk mengukur kepuasan mahasiswa terhadap pelayanan yang diberikan prodi bisnis jasa makanan FEB UAD, penelitian ini menggunakan metode IPA untuk keseluruhan aspek, sebagaimana tampak pada gambar 3.7. Gambar 3.7 menunjukan bahwa empat belas (14) atribut terdapat pada kuadran A, tujuh (7) di kuadran B, lima (5) di kuadran C, empat belas (14) berada pada kuadran D.

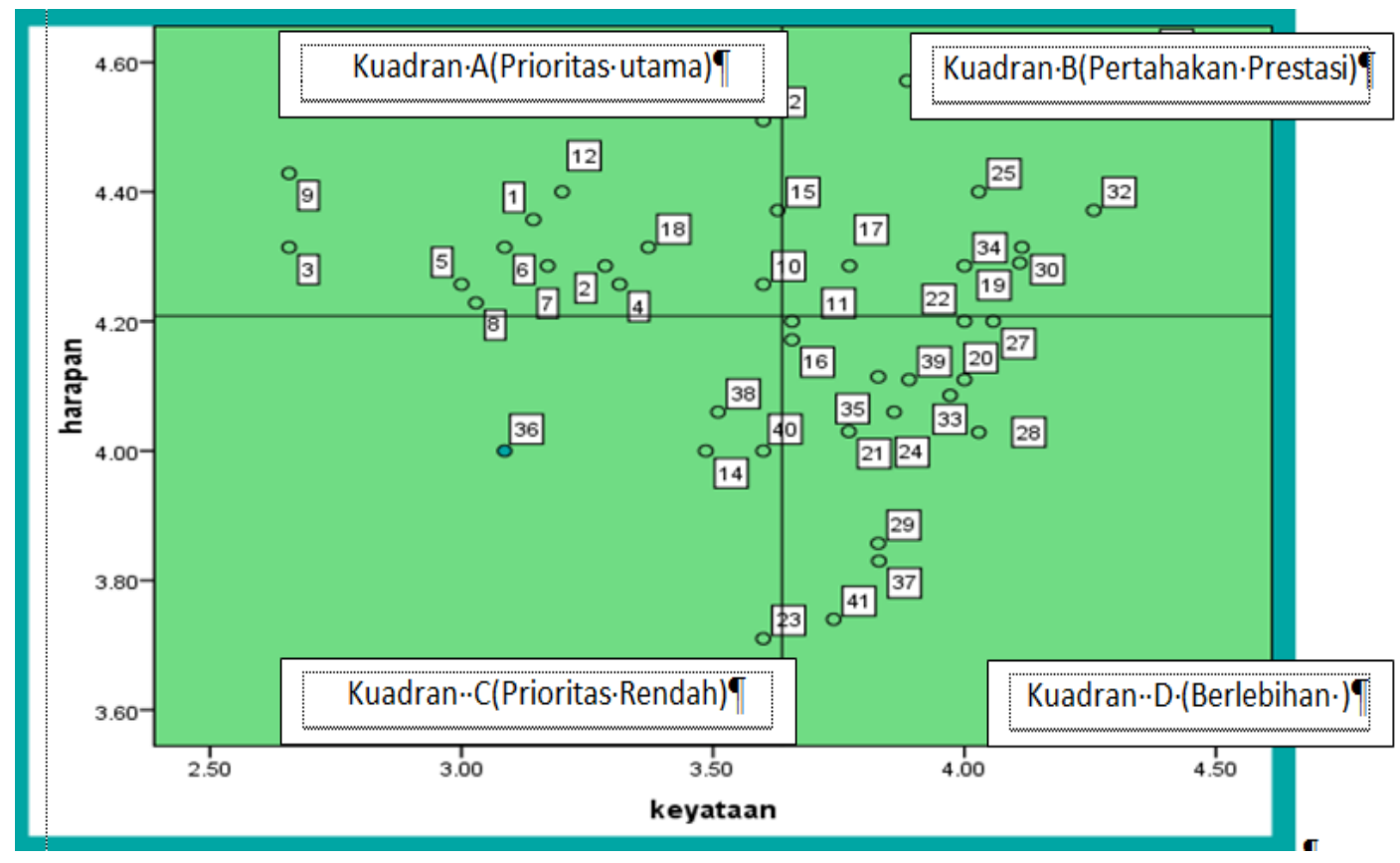

Gambar 3.7. Diagram Kartesius Semua Aspek

Sumber: Data Primer yang Diolah (2019)

Kuadran A adalah prioritas utama dimana mahasiswa sebagai responden merasakan atribut tersebut sangat penting dan mempunyai harapan tinggi namun belum merasakan kinerja yang maksimal. Adapun atribut tersebut:

1. (1) Ruang kuliah tersedia

2. (2) Ruang kuliah tertata dengan bersih, dan rapi

3. (3) Ruang kuliah sejuk dan nyaman

4. (4) Sarana pembelajaran yang tersedia di ruang kuliah.

5. (5) Prodi Bisma mempunyai perpustakaan yang lengkap

6. (6) Prodi Bisma mempunyai Laboratorium yang relevan dengan kebutuhan keilmuan bagi mahasiswa

7. (7) Ketersediaan buku referensi yang di perpustakaan

8. (8) Ketersediaan fasilitas kamar kecil yang cukup dan bersih

9. (9) Fasilitas ibadah yang dapat dipergunakan oleh mahasiswa di Program Studi Bisnis Jasa Makanan

10. (10) Kejelasan materi perkuliahan diberikan dosen

11. (12) Bahan ajar suplemen (handout, modul, dll) yang diberikan kepada mahasiswa untuk melengkapi materi perkuliahan

12. (15) Dosen memadai sesuai dengan bidang keahliannya 
13. (18) Kualitas layanan staf akademik untuk memenuhi kepentingan mahasiswa

14. (42) Program Studi Bisnis Jasa Makanan secara transparan dalam menjelaskan penggunaan dana

Kuadran B menunjukan keberadaan keberadaan atribut layanan yang juga dianggap penting oleh mahasiswa dan kinerjanya sudah dianggap baik oleh mahasiswa, oleh karenanya Program Studi Bisnis Jasa Makanan harus memepertahankan kinerja atribut ini supaya dapat terus menjadi lebih baik dan terus memenuhi apa yang menjadi harapan mahasiswa dan diharapkan juga dapat menjadi kekuatan program studi sebagai proses positif word of mouth. Hasil analisis menunjukan adanya empat atribut yaitu:

1. (16) Dosen mengembalikan hasil ujian/tugas dengan nilai yang obyektif.

2. (17) Kemampuan staf akademik untuk melayani administrasi kemahasiswaan

3. (19) Program Studi Bisnis Jasa Makanan menyediakan Dosen Bimbingan Konseling bagi mahasiswa

4. (25) Staf administrasi akademik santun dalam memberikan pelayanan

5. (30) Permasalahan/keluhan mahasiswa ditangani oleh Program Studi Bisnis Jasa Makanan melalui Dosen PA (Pembimbing Akademik).

6. (32) Waktu dipergunakan secara efektif oleh dosen dalam proses pengajaran

7. (34) Sanksi bagi mahasiswa yang melanggar peraturan yang telah ditetapkan Program Studi Bisnis Jasa Makanan dan berlaku untuk semua mahasiswa tanpa terkecuali

Atribut-atribut layanan yang berada dalam kuadran $\mathrm{C}$ adalah mahasiswa tidak mempunyai harapan terlalu tinggi sehingga tingkat kepentingannya tidak mendapat penilaian tinggi dan kinerjanya juga nilai biasa-biasa saja, sehingga Program Studi tidak harus memberikan fokus perbaikan untuk atribut layanan yang ada dalam kuadran ini. Berikut atribut yang berada dalam kuadran ini adalah sebagai berikut:

1. (14) Dosen datang tepat waktu

2. (23) Program Studi Bisnis Jasa Makanan memberikan bantuan pengobatan bagi mahasiswa yang sakit

3. (36) Program Studi Bisnis Jasa Makanan berusaha memahami minat dan bakat mahasiswa dan berusaha untuk mengembangkannya

4. (38) Program Studi Bisnis Jasa Makanan memberikan informasi akademik dan pelayanan non akademik dalam bentuk website

5. (40) Program Studi Bisnis Jasa Makanan membuka layanan pengaduan bagi mahasiswa yang memiliki permasalahan

Kuadran D menunjukan keberadaan atribut layanan yang menurut mahasiswa kinerjanya sudah baik bahkan cenderung melebihi apa yang diingikan mahasiswa karena sebenarnya mahasiswa tidak terlalu mempunyai harapan pada atribut layanan ini, sehingga tidak perlu memeberikan fokus pada atribut yang berada dalam kuadran D. Atribut yang berada dalam kuadran D ini adalah sebaga berikut :

1. (11) Waktu yang disediakan untuk diskusi dan tanya jawab

2. (16) Satuan Acara Perkuliahan yang dibuat dosen 
3. (21) Program Studi Bisnis Jasa Makanan menyediakan beasiswa bagi mahasiswa yang tidak mampu

4. (22) Program Studi Bisnis Jasa Makanan membantu mahasiswa apabila menghadapi masalah akademik

5. (24) Pimpinan Program Studi Bisnis Jasa Makanan beserta jajarannya menyediakan waktu bagi orang tua mahasiswa untuk berkonsultasi

6. (27) Program Studi Bisnis Jasa Makanan memberikan bantuan asuransi bagi mahasiswa yang mendapatkan musibah kecelakaan

7. (20) Permasalahan/keluhan mahasiswa ditangani oleh Program Studi Bisnis Jasa Makanan melalui dosen bimbingan konseling

8. (28) Setiap pekerjaan/tugas selalu dikembalikan pada mahasiswa

9. (34) Program Studi Bisnis Jasa Makanan memonitor terhadap kemajuan mahasiswa melalui dosen Pembimbing Akademik atau dosen bimbingan konseling

10. (35) Dosen bersikap terbuka, kooperatif dengan mahasiswa

11. (33) Program Studi Bisnis Jasa Makanan memberikan informasi sistem perkuliahan dalam bentuk buku panduan perkuliahan

12. (29) Program Studi Bisnis Jasa Makanan secara terbuka memberikan informasi dan pelayanan baik akademik maupun non akademi

13. (37) Program Studi Bisnis Jasa Makanan berusaha memberikan respon positif setiap pengaduan mahasiswa

14. (41) Program Studi Bisnis Jasa Makanan berusaha memberikan respon positif setiap pengaduan mahasiswa.

\section{Kesimpulan dan Saran}

Semakin ketatnya persaingan dengan perguruan tinggi yang membuka program studi sejenis baik di negeri maupun swasta meningkatkan urgensi evaluasi dan perbaikan mutu penyelenggaraan pendidikan dalam pelayannya kepada mahasiswa. Karena itu perlu diadakan evaluasi kualitas pelayanan pendidikan secara berkala.

Berdasarkan hasil pengujian terhadapdata dari 35 responden penelitian, maka dapat diambil kesimpulan sebagai berikut:

1. Kualitas pelayanan pendidikan di Prodi Bisma dapat dikatakan cukup baik, beberapa aspek pelayanan sudah mendekati harapan mahasiswa, beberapa yang lain masih jauh dari harapan. Tetapi dengan pengamatan secara detail ada beberapa aspek yang sudah membuat mahasiswa merasa puas dengan pelayanan. Dari keenam aspek yang ada, secara berurutan dari yang belum memenuhi sampai yang sudah mendekati harapan mahasiswa adalah: aspek tangibel, aspek reliability, sistem informasi, assurance, responsiveness, dan empathy.

2. Kualitas pelayanan juga dapat diukur dari banyaknya aspek yang telah dapat membuat mahasiswa merasa puas. Faktor-faktor tersebut adalah :

a. Ketersediaan ruang kuliah,

b. Perpustakaan,

c. Laboratorium

d. Dosen yang profesional

e. Ketersediaan materi perkuliahan dan suplemen 

f. Staf administrasi yang profesional
g. Ada keterbukaan dalam penggunaan dana mahasiswa secara proporsional
h. Kepedulian Prodi terhadap masalah yang dihadapi mahasiswa, baik yang bersifat akademik maupun non akademik

3. Dari analisis kesenjangan yang adaantara harapan mahasiswa dengan kenyataan yang diperoleh mahasiswa, dapat disimpulkan sebagai berikut:
a. Gap pada aspek tangibel sebesar -1,23
b. Gap pada aspek reliability sebesar $-0,70$
c. Gap pada aspek responsiveness sebesar -0,18
d. Gap pada aspek assurance sebesar $-0,32$
e. Gap pada aspek emphaty sebesar $-0,20$
f. Gap pada aspek sistem informasi sebesar -0, 35

4. Penelitian ini menunjukkan bahwa Gap terbesar terjadi pada aspek tangibel. Itu artinya bahwa Program Studi Bisnis Jasa Makanan perlu meningkatkan aspek ini supaya tetap menjadi pilihan calon mahasiswa di masa mendatang. Jadi, tanpa mengecilkan arti aspek lainnya, sumber daya fisik tetap menjadi pilihan mahasiswa dalam menentukan pilihan prodi yang diharapkan.

Dari kesimpulan tersebut, penulis menyarankan :

1. Meningkatkan beberapa aspek yang belum dapat membuat mahasiswa merasa puas atas pelayanan yang diberikan oleh Program Studi Bisnis Jasa Makanan, terutama yang terkait dengan sumberdaya fisik

2. Mempertahankan dengan terus meningkatkan beberapa aspek yang telah dapat membuat mahasiswa merasa puas, terutama yang terkait dengan sumberdaya manusia yang melakukan pelayanan di Program Studi Bisnis Jasa Makanan.

\section{Pustaka}

Beaumont, D. 2012. Service Quality in Higher Education: The Students' View Point. BSc (Honors) in Management. USA: Manchester University Manchester Business School.

Dado, J., Taborecka Petrovicova, J., Riznic, D. \& Rajic, T. 2011. “An Empirical Investigation into The Construct of Higher Education Service Quality", dalam International Review of Management and Marketing. Vol. 1, No. 3: 30-42.

De Oliviera dan Fereira. 2009." Adaptation and Application of The SERVQUAL Scale in Higher Education”, dalam POMS 20th Annual Conference, Orlando, Florida, USA.

Douglas, et.al. 2006. "Measuring Student Satisfaction at A UK University", dalam Quality Assurance in Education. Vol. 14, No. 3: 251 - 264.

Galloway, L. 1998. "Quality Perceptions of Internal and External Customers: A Case Study In Educational Administration”, dalam The TQM Magazine. Vol. 10, No. 1: 20-27. 
Hill, F. M., 1995. "Managing Service Quality in Higher Education: The Role of The Student As Primary Consumer", dalam Quality Assurance in Education. Vol. 3, No. 3: 10-21.

Jongbloed, B., Enders, J., Salermo, C. 2008. Higher Education And Its Communities: Interconnections, Interdependencies And A Research Agenda. Dalam Higher Education, 56, hlm. 303-324.

Kasetwar, R. B. 2008. "Quality in Higher Education", dalam University News. Vol. 46, No. 20: 6-12

Kotler dan Keller. 2012. Manajemen Pemasaran, Edisi 12. Jakarta: Erlangga.

Landrum, H., Prybutok, V. R., \& Zhang, X. 2007. “A Comparison of Magal's Service Quality Instrument With SERPERF", dalam Information and Management. Vol. 44: 104-113

Leisyte, L., Westerheijden, D. F., Epping, E., Faber, M., de Weert, E. 2011. Stakeholders and Quality Assurance in Higher Education, Center for Higher Education Policy Studies, Lausanne.

Lovelock, C, dan John Wirtz. 2011. Pemasaran Jasa Perspektif Edisi 7. Jakarta: Erlangga.

Maric, I. 2013. "Stakeholder Analysis of Higher Education Institutions", dalam Interdisciplinary Description of Complex Systems. Vol. 11, No. 2: 217-226.

Parasuraman, A., Zeithaml, Valerie A., dan Berry, Leonard L. 1985. "Servqual: A Multiple-Item Scale for Measuring Consumer Perception of Service Quality”, dalam Journal of Retailing. Vol. 64, No. 1: 12-40.

Prabowo, Sugeng Listyo. 2009. Implementasi Sistem Manajemen Mutu ISO 9001:2008 di Perguruan Tinggi (Guidelines IWA-2). Malang: UIN Malang Press.

Stamatis, D.H. 1996. Total Quality Service: Principle, Practice, \& Implementation, Singapore: SSMB Publishing Division.

Tjiptono, F., \& Chandra, G. 2016. Service, Quality dan Satisfaction: Edisi 4. Yogyakarta: Andi.

Tjiptono, Fandy. 2011. Pemasaran Jasa. Malang: Bayumedia.

Zafiropoulos, C.; and Vrana. V. 2008. "Service Quality Assessment In A Greek Higher Education Institute", dalam Journal of Business Economics and Management. Vol. 9, No. 1: $33-45$. 
